\title{
Writing children's geography books: Challenges, experiences, and observations
}

\section{Löytönen, Markku}

Springer International Publishing

2019-10-22

Löytönen , M \& Kaivola , T 2019 , Writing children's geography books: Challenges, experiences, and observations . in Handbook of the Changing World Language Map . Springer International Publishing , pp. 3507-3520 . https://doi.org/10.1007/978-3-030-02438-3_197

http://hdl.handle.net/10138/336804

https://doi.org/10.1007/978-3-030-02438-3_197

acceptedVersion

Downloaded from Helda, University of Helsinki institutional repository.

This is an electronic reprint of the original article.

This reprint may differ from the original in pagination and typographic detail.

Please cite the original version. 


\title{
The Challenge in Writing Children's Geography Books: Experiences and Observations
}

\author{
Markku Löytönen \\ Professor of Geography, Department of Geosciences and Geography, University of Helsinki, Finland, \\ markku.loytonen@helsinki.fi

\section{Taina Kaivola} \\ Retired Pedagogical University Lecturer, Faculty of Science, University of Helsinki, Finland, \\ penttinen.jukkapekka@gmail.com
}

\begin{abstract}
Libraries, museums and other repositories, science parks, fairs, the internet, electronic entertainment and movies are all, for today's children, natural channels for picking up new ideas. How then should we make an appealing learning tool for children and young adults when all we have at our disposal are printed words and images, i.e. books, and when all manner of distractions compete for their attention? In what follows we examine these questions from a general pedagogical perspective as well from the experience gained in producing five works of non-fiction intended for children.
\end{abstract}

\section{Keywords}

Education, children, non-fiction, literature, learning environments

\section{Introduction}

If you ask an experienced teacher how to get a student/pupil to learn effectively, more often than not the answer is interaction. You have achieved your goal when you have established contact with the student/pupil. And everything else follows on from that. Indeed, certain scholars have defined the criteria for successful learning in terms of a further three factors: the student/pupil's willingness to learn, sufficient resources for learning, and a supportive learning environment. None of these depends solely on the teacher. This "recipe or mix" should come as no surprise since the bulk of learning takes place outside of school. Libraries, museums and other repositories, science parks, fairs, the internet, electronic entertainment (computer games) and films/movies are all, for today's children, natural channels for picking up new ideas. When you add to these "voluntary" learning environments a solid foundation provided by home and the child's peer group in forming his or her world-view, it is clear that non-fiction authors whose work is intended for children need to approach the reader from an entirely different standpoint than, say, the teacher.

How then should we make an appealing learning tool for children and young adults when all we have at our disposal are printed words and images, i.e. books, and when all manner of distractions compete for their attention? How might we construct a work of non-fiction such that reading and browsing through it could support the learning process by promoting interaction? And what kind of text would it have to be that the material could form part of the child's or young person's own story/narrative, a text by means of which the events described and factual matter presented could be integrated into prior understanding? In what follows we examine these questions from a general pedagogical perspective as well from the experience gained in producing several non-fiction books for children of which one only has been translated and published into English (Löytönen \& Waismaa 1996, 2001; Löytönen \& Jäntti 2005, 2007). The one will be included as a reference for an example (Löytönen \& Jäntti 2005).

\section{Children and the Media}

Our investigation into the viewing habits of 10-14-year-olds began at the end of the 1980s. The most popular programs turned out to be hero narratives, events in which bore numerous retellings among friends. According to the findings, a narrative structure seemed to match children's particular need to know better and more than the systematic knowledge provided through schooling. Since the period under investigation, television programming and viewing habits have changed. Children watch more and more reality TV shows in which the lone, courageous and resourceful hero has been replaced: viewers now get 
to choose any one of the roles in the show to an identify. And yet the tales of heroic deeds persist in the world of the child and young adult, having largely been transferred to PC and game consoles. In this context, the child is no longer a mere outsider passively following the hero's adventures, but instead plays an active part in shaping the narrative line (Kytömäki 2001; Kaivola \& Rikkinen 2003).

The most recent shift in media culture involves a blurring of the boundary between fact and fiction. In terms of the developing child's sense of reality, it may be a more complex and meaningful factor than the violence meted out in films/movies or by robots on the PC and game consoles. Children learn the difference between fact and fiction at a very early age, but when the boundary between them is purposefully blurred by reality TV programs, the need to relate factual stories to children and young adults is all the more important. In this respect, illustrative and structured works of non-fiction are key (Herkman 2001; Juuti 2005).

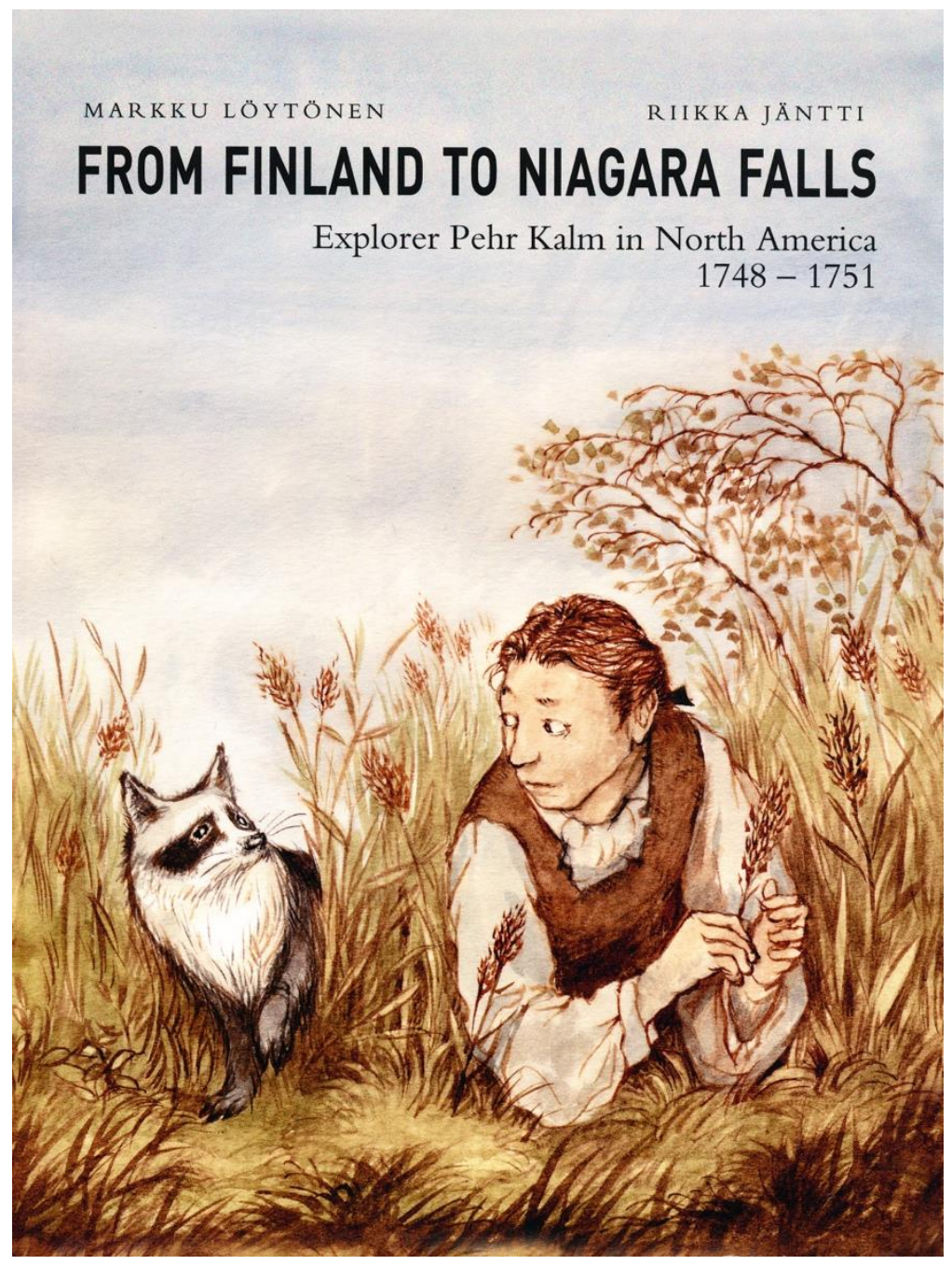

Fig. 1 Title page of the book for figures.

\section{Tell a Fascinating Story}

How do we get a person in their early teens to commit to reading and learning when what is at issue is, say, a geography book? Everything is about the story. It should be made interesting, even exciting, and draws the reader in, and maintaining a level of interest to the very end. The story needs to be constructed by segueing from one interesting episode to the next. A single page or centerfold covers a single episode. For preschool children (up to age six in Finland), the "natural" reading experience is still one of proceeding page by page and, where necessary, can be divided into manageable stretches of reading, such as bedtime stories. 


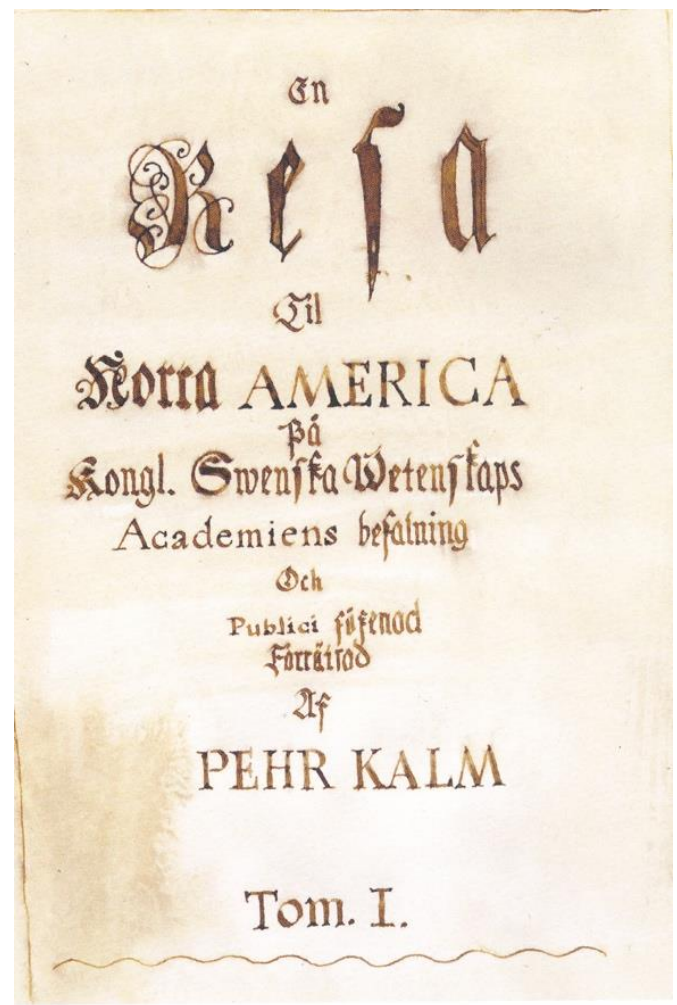

Fig. 2 Title page of Pehr Kalm's first edition of his travel to North America.

The language has to be lively and not just one sentence plonked after another. Compared to a textbook then, a children's work of non-fiction has to be written in a far livelier style. The text has to include elements that set up the possibility for, even challenge, reading abilities at various levels: skimming, scanning, inferential and empathetic reading. In the 2000 PISA (the OECD's Programme for International Student Assessment), 15-year-old Finnish pupils did much better than their counterparts in other OECD countries in literacy tasks which measured the ability to find information and interpret texts. After South Koreans, Finns also came top in tasks measuring factual literacy, in areas covering natural sciences such as geography, the environment, technology and health. However, in research conducted into the schoolleaving, or "matriculation" examinations, it was demonstrated that candidates wrote on broad environmental topics, drawing for their claims and opinions on their reading of weekly and periodical magazines as well as information gleaned from other media sources. With respect to geography, biology and other natural science courses in senior secondary school/high school, little or no reference was made to teach information or the candidates' personal experience. In data covering approximately 900 examination scripts there was little indication of serious reflection on the causes and consequences of environmental problems. From the results, it can be determined that the scientific information imparted by textbooks fails to be integrated into young adults' knowledge, at least in a way that writing or telling about it would come naturally beyond the classroom in which it is taught.

\section{Illustrations and Narrative Complexity Help}

The illustration in children's' non-fiction is important first and foremost in terms of the very decision to read (choosing a book in the library or bookstore) and also in the telling of the narrative and constructing the work's narrative complexity. The main illustration has to be supported by the title, which is good to take into account when considering the chapter breaks in the narrative. However, it is good to make full use of the space on individual pages by either adding visual elements with accompanying text or collecting small inset illustrations on engaging themes relevant to the story. 


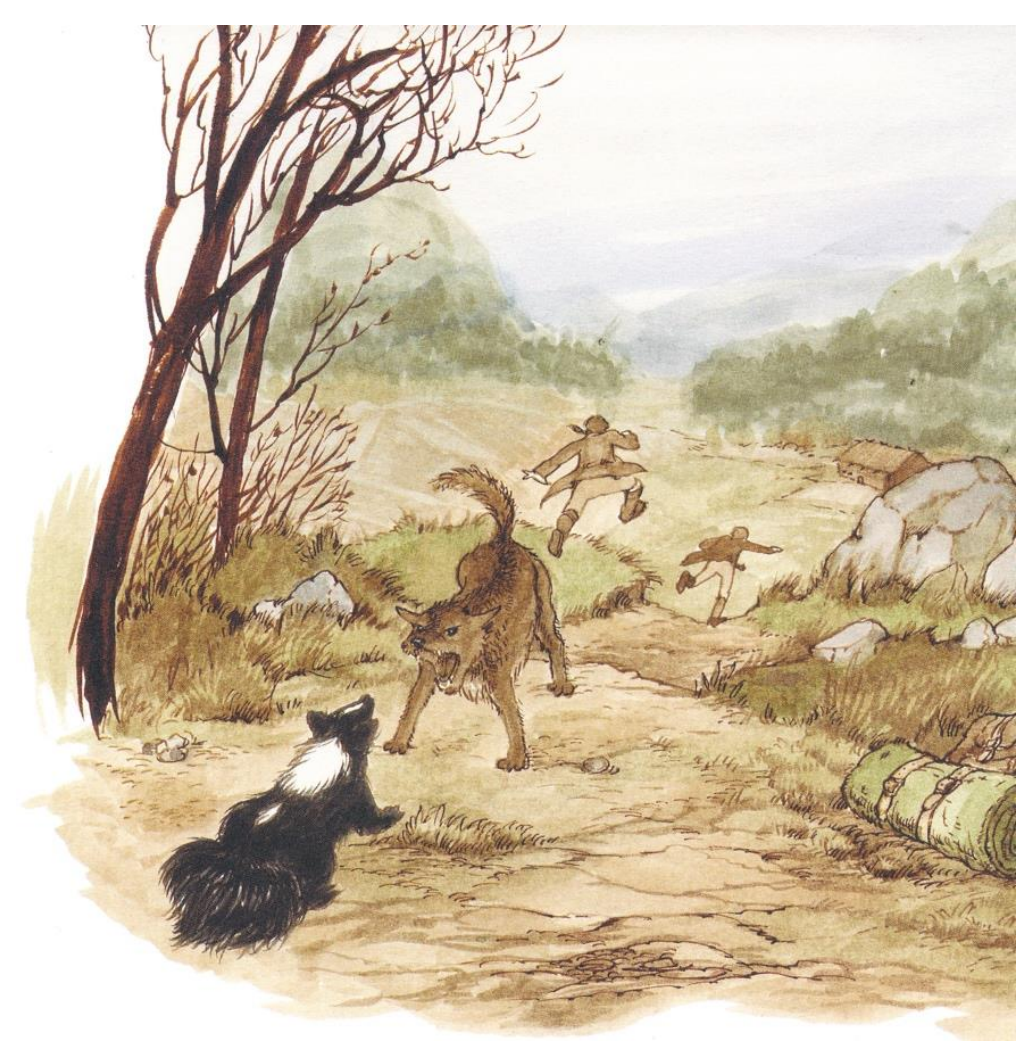

Fig. 3 Attack by a skunk.

By way of example, in the book telling about Pehr Kalm's voyage to North America the small illustrations depict flora and fauna relevant to the story and are positioned with a view toward advancing the storyline (Leikola 1989; Löytönen 199089). In addition to the local flora, these pictures feature birds, small mammals and reptiles. The themes of the small illustrations mirror the character of the journey, in essence the journey of a naturalist and explorer. Another example is the book on Georg August Wallin's explorations in Arabia (Löytönen 2000. The themes selected include the doctor's implements taken on his early travels (Wallin dressed as a Bedouin and offered his services as a medical doctor), the vegetation in the oases, coffee pots, dates and other foodstuffs enjoyed on the desert travels, as well as other representations of Bedouin material culture. In the book dealing with the Finn Herman Spöring Jr, who accompanied James Cook on his voyages, there are illustrations of objects relating to sailing, sea charts and trigonometry. The book centering on Adolf Erik Nordenskiöld (1832-1901), who sailed through the North-East passage, quite naturally features the flora and fauna of the Arctic and northernmost parts of the Eurasian continent, together with instances of the local inhabitants' material and social culture (Löytönen 1989a and b).

It may easily escape the notice of the reader just how much archival research goes into selecting the illustrations. In non-fiction, the events depicted pictorially and details therein have to be drawn and painted with precision. Even the slimmest of volumes requires dozens of illustrations, the details of which have to be carefully checked for accuracy. In itself a straightforward illustration of a Native American Indian firing an arrow means the illustrator has to delve thoroughly into the topic. The bow and quiver have to match those in Kalm's description of his encounter with the Indian. The same goes for the headdress and clothing, complete with all its decoration. Illustrations of the ship are best drafted on the basis of contemporary sketches, blueprints or accurate scale models. The watercolor of HMS Endeavour, the ship in which James Cook first circumnavigated the world, was painted in the Maritime Museum at Greenwich, London, taking a detailed scale model as its basis. If the protagonists in the narrative have recognizable features, these too have to be replicated as accurately as possible. However, this does not always work. There are, for example, no known pictures of Herman Spöring Jr. And recently the portrait said to be that of Pehr Kalm has been shown to be that of another professorial Pehr at the Royal Turku Academy: Pehr Gadd. 


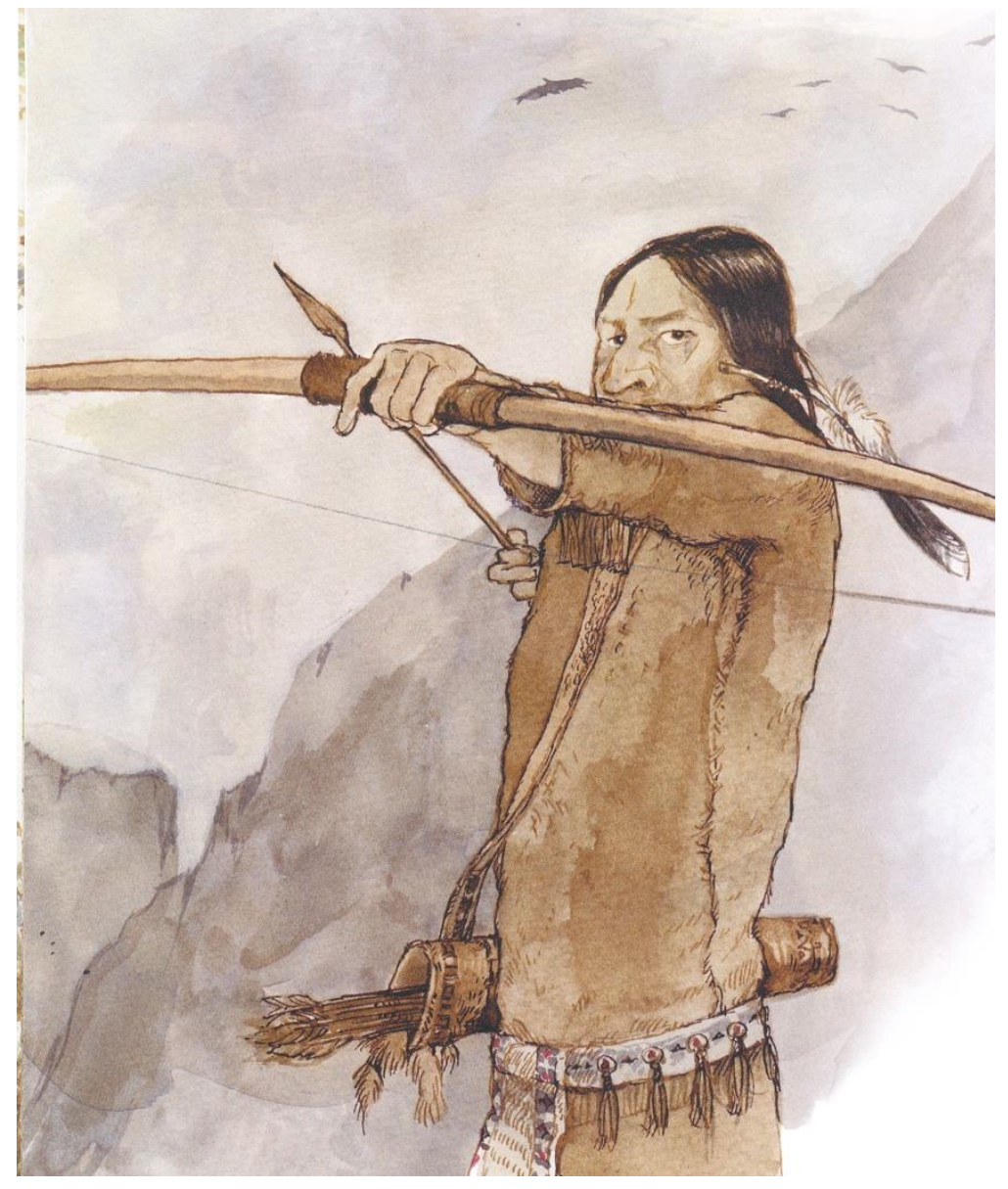

Fig. 4 A Native American.

\section{For Whom Are You Writing?}

Defining the age group of the readership is vital because it determines the readability of the text (Löytönen \& Waismaa 2001). This goes for every stage of the writing process. For the first book in the series, the readers' target age was two years either side of eight years old. This means the age at which the child has become literate and can read the book by her/himself. Children aged five represent the lower end of the target age group, the age at which the child is read to. We have received feedback suggesting that the book interests children whilst not necessarily appealing to the adults reading to them. For this reason, the target age group for the following three books was raised to ten with a greater range of three rather than two years either side of the target age. The lower limit was kept at five. This meant we could increase the degree of difficulty and lengthen the text. However, more important was to ensure that the shift in approach meant that issues that were closer to the adult world could be dealt with. It was then feasible to cite field notes or letters. Following this change, adults too have shown their appreciation of the books. Two citations in the Wallin book explain how an adult can be drawn in a work of non-fiction aimed at a child:

"What more do I have to do with Europe, a continent which has become almost entirely alien to me? I could spend the rest of my days in the company of desert boys herding camels and sheep and equally enjoy the simplicity of the desert, far from the vanity and overrefined civilisation of Europe." (Wallin writing from Finland to his beloved Bedouin princess on 2 August 1847)

"One went to Mecca and bathed in the clear but pungent waters of Zamzam, the other in the waters of Jordan. Another made the sign of the cross at some grave, yet another toured an ugly old tower-like edifice and kissed a black stone. Which of these is wisest? Only God knows." (Wallin's diary entry for 30 March 1847) 
Its central narrative, the main illustration, small themed illustrations and a variety of citations all point to a complex narrative structure, something that readers of all ages can tackle in their own way. Observations made by media researchers indicate that children greatly appreciate television viewing in the company of adults. However, they only enjoy watching television when it reaches a certain threshold level of interest to them. For all intents and purposes the circumstances of reading non-fiction are the same as watching popular scientific or nature programs: when an adult gets interested in a book and reads it with a child, an interactive environment, conducive to learning, is there for the taking (Löytönen \& Waismaa 2001).

\section{Humor}

Humorous writing is demanding, but incredibly effective, even when it comes to teaching adults difficult and complex matters. Perhaps the best exemplar of this style of writing non-fiction for children is, to our minds, Mauri Kunnas. The paperback series The terrible truth about chemistry, dealing with space, mathematics, the Middle Ages etc. probably best represents this genre (Nick \& de Saulles 2000). A marvelous sense of humor and perceptive language runs throughout the series like a bright thread, weaving together the content into a seamless narrative whole.

A review of our own four books reveals that humor is used sparingly and only then with reference to actual events. The Nordenskiöld text includes a passage in which Nordenskiöld describes the Vega, the ship frozen solid in the ice, as the "world's most northerly restaurant." The eternally hungry tsuksi were, it seems, forever pestering the ship's crew for food and alcoholic beverages. In the book on Pehr Kalm, the ordeal by a skunk is described pretty much as the explorer described it in his diary. The opinion of an eleven-year-old reader, Jussi, reveals nicely how subtle humor offers an aid to learning and all the more so since the young reader barely registers it. In Jussi's own words:

"This feels more like a storybook than a book about real things. There are these pictures of plants and animals but no writing under the pictures except to say where you find them. Only problem is in this book you can't run away from the skunk!"

A certain "stuffiness" is also avoided by skipping the factsheet inserts so beloved of contemporary textbooks. Even though the language of the books dealing with explorers is purposefully factual, in each of them the text is driven forward by the adventures of a central figure, animated by an apparently authentic specimen and illustrations. 


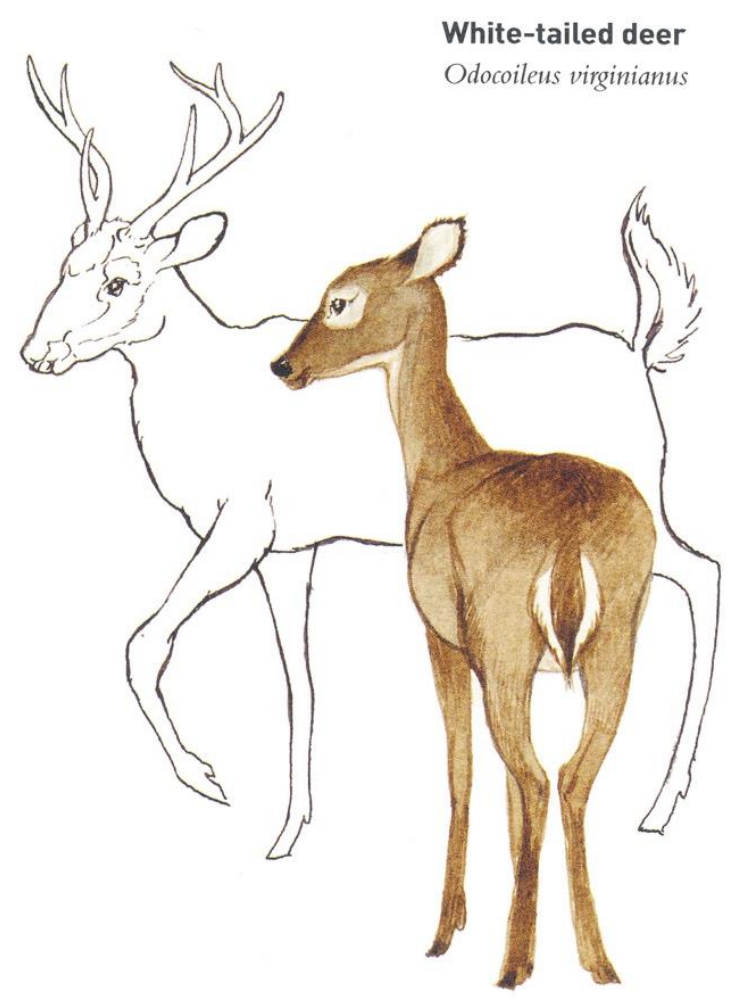

Fig. 5 Example of a detail.

\section{How to Describe Unfamiliar Places}

In writing about explorers, the author was constantly up against the problem faced by the geographer of how to depict unfamiliar places and cultures. According to our chosen theory of learning, everything we learn derives from what we already know about something, what we believe or what we believe we know. Teaching, especially in physics and chemistry, takes account of these preconceptions, since there exists a strong disconnect between everyday expressions and scientific language in these fields. And yet everyday experience oftentimes holds broadly true, albeit scientific theories may adjust and refine it. The orientation of geography is often easier than other natural sciences. After all, a place name may be the object of a decision and change over time. And geography has paid a lot of attention to the teaching of concepts. A (thorough) understanding of a new concept requires the ability to interpret the theory and research that underlies it.

Since what we learn melds with our individual experience, it seems reasonable to incorporate into the main narrative of non-fiction works a suitable number of elements that the young reader can identify with. There needs to be a "hook," whilst recognizing when to avoid platitudes. In geography and natural sciences, there is generally plenty to draw on from everyday experience. This makes it all the more baffling in our view that geography textbooks, particularly those dealing with specific regions, cling on superficially to GDP, state borders and place names on maps with have little or no meaning to a ten-yearold. On the other hand, small children can be extremely interested in things that are at a considerable distance removed, both temporally and spatially, that is, things that at least previously had been deemed too difficult for them. Commercial media and firms have, in many ways, been able to exploit this natural gift for wonder and imagination in marketing their products. This is something that the production of teaching material has largely failed to do, given that the interest in studying natural sciences as part of the general curriculum appears to be on the wane.

\section{Respect the Historical Period}

Telling a story has to be honest and faithful to its period. Historical reality should be depicted in accordance with the prevailing outlook of the historical period, not least when it seems alien to the values 
of the present. Kalm witnessed the transportation of slaves to North America and gave accounts of their status and treatment with the scientific neutrality of an external observer. He did not moralize about what he saw, but certainly reflected on their legal status. To assist the young reader, an ahistorical comment has been added to the text to the effect that what was at issue was a cruel trade in human life. However, this aside, is there in order to prompt reflection and discussion if the book is read to the child by an adult? Similarly, Kalm observed and described the aboriginal inhabitants he encountered in North America without commenting on their vassalage to their colonial masters.

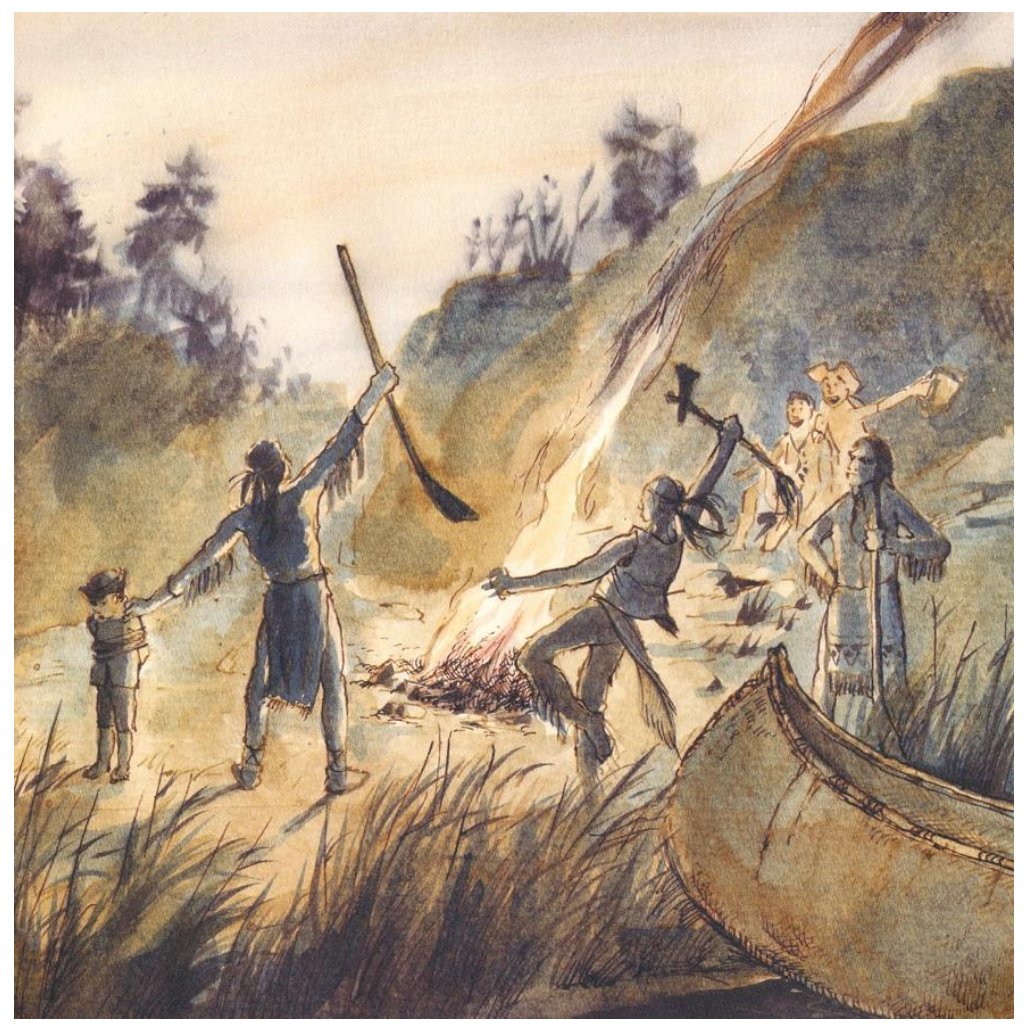

Fig. 6 Native Americans celebrating.

If there is a need for value-based discussion, it is best left to the book's foreword or a separate introductory address to the reader. In this way the integrity of the historical period in question is respected and, for example, strengthening stereotypical perceptions about aboriginal peoples can be avoided. Kati's comments on the Kalm book show just how difficult this can be to do. In her opinion the text gave an overly simplistic picture of the native Indians as violent "baddies," despite the author's best efforts to remain neutral in his presentation. The Nordenskiöld book's preface, for its part, explains what exploration in that age was really all about:

"Voyages of discovery and exploration over millennia have often seemed to us little more than foolhardy adventures. Accounts of the journeys tell of fearless men and women who travelled overland and by sea, sometimes fighting pirates, sometimes conquering entire continents for the home country. But whether it is a made-up story or a real journey, this notion of oceans and adventurers in the jungle is mostly misleading. No doubt some travellers were adventurers, but the basic reason for organising the expeditions were entirely mundane. At issue were primarily the policies of the great powers and trade interests in particular, practiced both singly and jointly by the monarchs and trading bodies."

A particular source of difficulty, however, is the choice of place names. In principle, it makes perfect sense to use the nomenclature of the period, since it matches the circumstances of the time. This can present challenges for the novice reader and more experienced reader alike: place names from a bygone era can be tricky for the researcher to explain. One solution is to accompany the narrative with the best maps available, enabling readers to work out the nomenclature for themselves. Another option is to update 
place names and accept the fact that the work of non-fiction does not fit the historical events described. Whatever practice is adopted, there is no single simple solution to the problem.

\section{The Importance of Providing Background}

The central narrative in non-fiction written for children should be shaped around a self-standing, complete whole, sufficient to convey a comprehensible account of the events portrayed (for example, the central protagonist's life events or the exploration), taking into account of the child's presumed knowledge and the textual structure. And defining the target age group is important here too: it tells the writer what the child was expected to have been taught at school. Indeed the Finnish National Board of Education was very particular in its 2004 curriculum for basic schooling. It follows that writing is often a matter of process, with a need for constant monitoring of the narrative's logic and comprehensibility.

One such example can be found in the Kalm book (Kaivola \& Penttinen 2004). The reader has to be given details of a great colonial war, because this relates to restlessness in border areas just a few years prior to the war. The Nordenskiöld manuscript needed several sentences by way of explanatory background, without which the novice reader would fail to catch all the twists in the narrative. The deportation order issued by Governor-General von Berg for Nordenskiöld?s removal was set in context a few pages earlier by adding two pieces of information to the narrative. Firstly, it was necessary to explain Finland's status as a part of the Russian empire and, as a corollary, to explain the internal political tensions arising out of the Crimean (or, as it was known at the time, Russian) War. In a single sentence, again there was a need to explain why anyone singing the Marseillaise was courting danger in the febrile political atmosphere. A young person today may find it difficult to understand why students' drunken revelry on the streets could incur the wrath of the state, whatever the lyrics. Here is the description of the event and the sentence offering an explanation:

"During one celebration in the autumn of 1855 students had proposed a number of toasts, some of them eulogising of the western forces. And to top it all, after the party when the students spilled out onto the streets, they sang a Swedish version of the Marseillaise. The song was from the 1789 French Revolution and encouraged bold declarations of freedom."

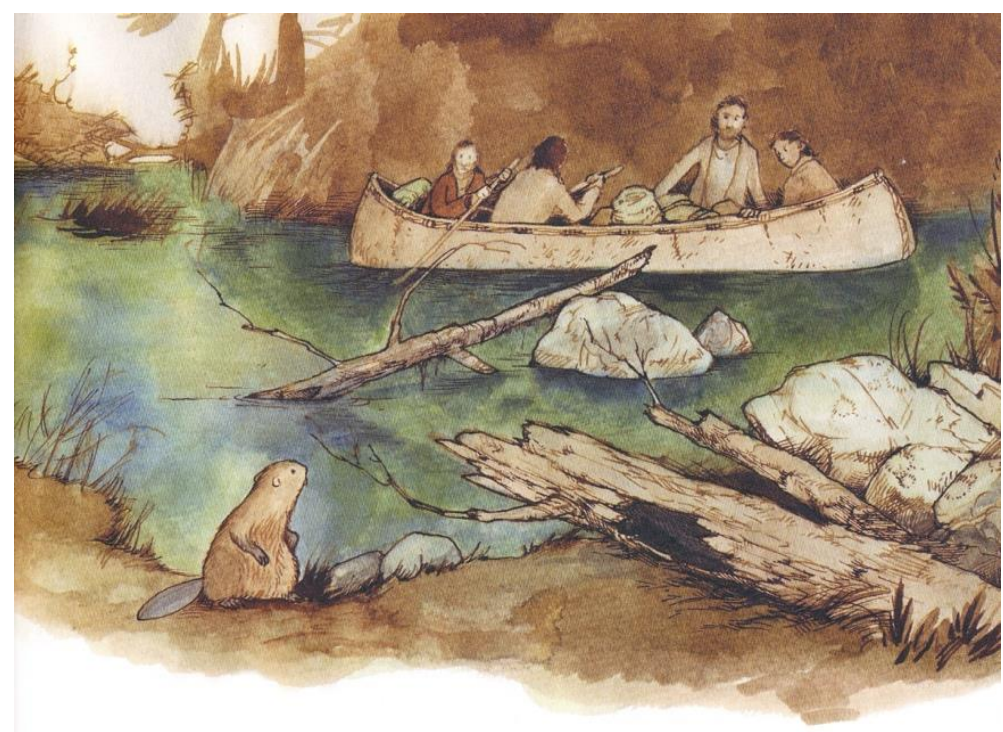

Fig. 7 Canoeing in the wilderness. 


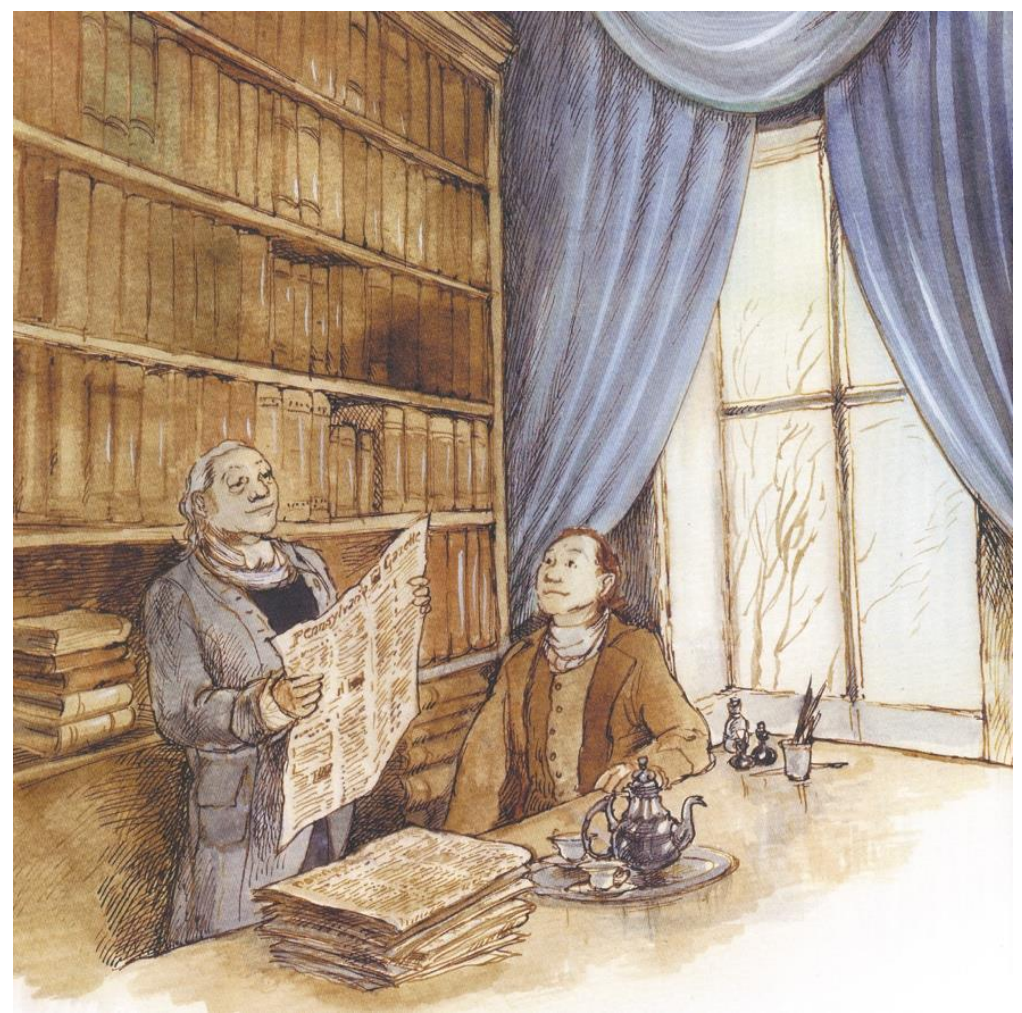

Fig. 8 Pehr Kalm with Benjamin Franklin.

\section{The Stigma of the Genius and Hard Work}

A child's idea about how science works has a lot to do with popular culture and Donald Duck's fellow cartoon poultry, Gyro Gearloose, building gadgets. It is a world where the discovery of genius is down to chance. It remains a mystery for many children how scientists arrive at a result and how their knowledge, according to scientific principles, contributes to an understanding of highly complex phenomena. Works of science fiction, television series and especially science fiction movies generate a sense of the unfathomable possibilities offered by technology.

Besides distinguishing between fact from fiction, the developing worldview of children and young people conditioned by media representations should not lose sight of questions of right and wrong. Constructing a base of ethical values is a demanding process; the child has plenty to reflect upon and discuss as she/he enters adulthood. The facts on which scientific knowledge is based as well as showing due consideration for other people and the environment are the keys to building a better life for oneself as well as for others in Finland, as elsewhere. In support of this endeavor, scientists can play their part by producing factual texts and teaching materials.

What can, or should we learn from writing non-fiction for children? From the writer's point of view, of the factors most conducive to learning mentioned at the outset of this article, it is the reader's desire to learn that seems to be of utmost importance. This includes arousing interest and sustaining it through the narrative, a narrative that encourages the child or young adult to think and use their imagination. In a bid to create a suitable learning environment, the writer's aims are furthered not least by appealing to the adult reader, too. Any guarantee of sufficient resources (in this case having to do with the close interaction between children and adults, and time spent together) is in practice beyond the gift of the author. The steps that promote the generation of new knowledge need to be both replicated and followed up - in other words, teaching methods should echo research methods.

\section{Example}

Aarkku Löytönen et Riikka Jäntti (2015). From Finland to Niagara Falls? Explorer Pehr Kalm in North America 1748-1751.37 p. Buffalo Heritage Press, Buffalo, NY, United States of America. 


\section{References}

Herkman, J. (2001). Median monet funktiot lasten ja nuorten elämässä [Media's Many Roles in the lives of Children and Adoscelents]. In Kangsassalo, M \& J. Suoranta (Eds.). Lasten tietoyhteiskunta [Childrens' Information Society], pp. 60-71. Tampere University Press, Tampere, Finland.

Juuti, K. (2005). Towards Primary School Physics Teaching and Learning - Design Research Approach. Research Report 256. 159 p. Helsinki University Press, Helsinki, Finland.

Kaivola, Taina \& Jussi Penttinen (2004). Tietokirja satukirjan kansissa [Non-Fiction for Children]. Terra 116: 3, pp. 212-213.

Kaivola, Taina \& Hannele Rikkinen (2003). Nuoret ympäristöissään [Adolescents in their Daily Environments]. 307 p. Finnish Lieterature Society, Helsinki, Finland.

Kytömäki, Jorma (2001). Kertomuksia kertomuksissa [Stories within Stories. In Kangsassalo, M \& J. Suoranta (Eds.). Lasten tietoyhteiskunta [Childrens' Information Society], pp. 49-59. Tampere University Press, Tampere, Finland.

Leikola, Anto (1989). Valistuksen vuosisadan suomalasia maailmalla [Famous Finnish Explorers of the 18th Century]. In Markku Löytönen (Ed.) (1989). Matka-arkku, suomalaisia tutkimusmatkailijoita [Finnish Explorers]. 430 p. Finnish Literature Cosiety, Helsinki, Finland.

Löytönen, Markku (1989a). Herman Dietrich Spöring nuorempi, tuntemattoman mantereen etsijä [Herman Dietrich Spöring Younger - An Explorer in James Cook's Retinue]. In Markku Löytönen (Ed.). Matkaarkku, suomalaisia tutkimusmatkailijoita [Finnish Explorers], pp. 24-35. Suomalaisen Kirjallisuuden Seura, Helsinki.

Löytönen, Markku (Ed.) (1989b). Matka-arkku, suomalaisia tutkimusmatkailijoita [Finnish Explorers]. Suomalaisen Kirjallisuuden Seura, Helsinki. 430 p.

Löytönen, Markku (2000). Mapping of the World. In Leena Pärssinen (Ed.). Terra Cognita, pp. 44-72. Helsinki university library, Helsinki, Finland.

Löytönen, Markku \& Riikka Jäntti (2005). Koillisväylän löytäjä. Tutkimusmatkaaja Adolf Erik Nordenskiöld Jäämerellä [Sailing the North-East Passage. Explorer Adolf Erik Nordenskiöld in the Arctic Ocean]. 46 p. Finnish Literature Society, Helsinki, Finland.

Löytönen, Markku \& Riikka Jäntti (2007). Viidakkotanssi. Tutkimusmatkaaja Rafael Karsten Ecuadorissa [Snakes and Headhunters. Explorer Rafael Karsten in Ecuador]. 44 p. Finnish Literature Society, Helsinki, Finland.

Löytönen, Markku \& Miisa Waismaa (1996). Eteläisten merten salaisuus [Secret of the South Seas]. 32 p. Finnish Literature Society, Helsinki, Finland.

Löytönen, Markku \& Miisa Waismaa (2001). Arabian salaperäinen vaeltaja. Tutkimusmatkaaja G. A. Wallin [Mysterious Explorer in Arabia - Explorer G. A. Wallin]. 40 p. Finnish Literature Society, Helsinki, Finland.

Nick, A. \& T. de Saulles (2000). Kaamea totuus kemiasta [The Terrible Truth about Chemistry]. 160 p. Tammi, Helsinki, Finland 